\title{
The Role of Information Technology on Management of Risks in the Capital Market (Case Study: Companies Listed in Tehran Stock Exchange)
}

\author{
Adele Sadat Fatemi ${ }^{1}$, Ali Sabbaghian ${ }^{2 *}$ \\ ${ }^{1,2}$ Department of Management, Naragh Branch, Islamic Azad University, Naragh, Iran *Corresponding \\ Author: asabbaghian@iau-naragh.ac.ir
}

\begin{abstract}
The aim of this study was to determine the impact of information technology in management of risks in the capital market-listed company is in Tehran Stock Exchange. The purpose of the present study is an applied descriptive approach. The target population for the survey, companies that from 2009 to the first half of 2015 have been a member of the Tehran Stock Exchange, through Cochran's sample size of 140 companies, respectively. We used cluster sampling method. In order to collect data from two questionnaires: risk management questionnaire Foakeh (2013) has 38 items and a standard questionnaire Chanvyas (2006) has 40 items, the whole five-item Likert scale questionnaire is above has been used. Data gathered through the questionnaire, sign the application was 21 spss. For inferential analysis of the variables and to analyze the data from different statistical tests and regression was used Kolmogorov-Smirnov test. The results showed that information technology on risk management and its dimensions (primary market risk, market risk and the risk of secondary non-financial) impact.
\end{abstract}

Keywords: Information Technology, Risk Primary Market, Secondary Market Risk, Non-Financial Risks, Risk Management

\section{Introduction}

The transformation of the global economy in recent decades and economic development have led to the development and development of numerous financial instruments. In addition to the expansion of traditional physical and financial assets, financial derivative transactions have also accelerated.

The uncertainty surrounding the environment and the intensity of the competition between organizations and managers has challenged them with many challenges. The interconnection of the Internet and electronic communications will put valuable studies in an inadvertently endangered manner. With every advancement in technology, new risks are created, many of the old risks remain, and as a result, the risk inventory (the cumulative frequency of risks) increases. As stated, there is no escape from risk, and human society must look for ways to deal with it. Decisionmaking in ITbased fields, projects and systems is also not risk-free and therefore, risk management policies and procedures should be considered in this area and supported by relevant decisions. In any organization that uses automated information technology systems to fulfill its mission and mission. Risk management plays a critical role in supporting the organization's information resources.

Risk management helps managers manage their operational and economic costs and help them make the best decisions. An appropriate risk management approach, if properly implemented, can help managers identify appropriate control factors. So as to ensure the security of the research mission of the organization and thus can guarantee the survival of the organization and protect the organization from the risk of small and large existing risks. In fact, the risk management process should be considered as part of a strong information security organization program. Because it is very necessary to apply risk management to support the organization and its mission in today's dynamic environment.

Newcomer upsurge in the IT industry in Iran and the high potential of experts as well as major organizations and institutions in the country have provided a good opportunity for serious attention to the development of IT expertise and infrastructures. Given the fact that today, the economic well-being of nations is directly related to their level of skills in information and communication technology, it is appropriate to provide ICT with the development of scientific and research fields. The development of IT infrastructure is something that will happen in the future, with issues such as educational development and cultural development, both of which are the tools of knowledge societies. Information 
technology as knowledge and as an industry has a high degree of entrepreneurship and as a result of its proper utilization and its managed development in Iran can have beneficial effects in our country's economic corpora.

\section{Literature Review}

Choline and colleagues (2015) state in an article entitled "Information and Communication Technology as a Key Strategy for Supply Chain Management for Small and Medium-Sized Manufacturing Companies": The importance of working in an analytical region (Aguascalinets)There were few studies on the manufacturing industry, especially in aspects related to factors that influenced productivity and thus competitiveness. A review of the supply chain management and the strategies followed by this industry explains the region's economic growth in recent years, improves its infrastructure, and dramatically increases the number of businesses, and most importantly, the main reason for almost all exports. The region has been; therefore, this research is especially needed for small and medium enterprises, despite the presence in the most dynamic sub sector in the industry, there are very challenging problems in terms of how to organize and how to link with other sectors in terms of overall productivity. In fact, the results indicate that ICT strategies and technology affect the performance of supply chain management. The use of communication technology and information management resources facilitates information and delays, which not only reduces costs but also increases customer satisfaction; thus, the overall competitiveness of the organization Strengthens.

Yang Huang and Chang Yong (2011), based on theoretical studies as well as expert opinion, provided a comprehensive definition of IT projects, then determined the scope and risk factors for IT projects. At the end, they introduced a framework for risk management of information technology projects. Feng and Lee (2010) relied on the security risks of IT projects to evaluate IT projects. In his view, moving away from uncertainty is the most influential factor in the success of the risk assessment of the IT project. Baly (2010) evaluated the relationship between expected volatility and expected returns in the portfolio portfolio selected by the New York Stock Exchange, using GARCH model estimates of conditional variance (risk), then the case The contract test, to which extent the conditional covariance predicts the expected basket performance. The result of the study indicated that the estimated covariance predicted by the GARCH model predicts the expected returns of the basket. Doosti et al. (2015), in a paper titled "The Study of the Relationship between Reducing Routing and Information Technology in Companies Accepted in the Securities Market", states: There is a significant relationship between the use of information technology in monitoring and reduction of roaming behavior. There is also a significant relationship between the use of information technology in monitoring and reducing the risk of non-disclosure of risk mitigation, the inherent risk reduction and risk reduction of control.

Nick Ghadam Hojjati and Jalilvand (2015) in an article entitled "Application of information security management system in reducing the risk of outsourcing of IT projects" states: The implementation of the information security management system is a strategy that uses policies, Controls and security settings appropriate to the organization protect the confidential information and intellectual property of the organization, personal information and customer data. Rabiei and Fathi (2015) in a paper titled "Identifying and ranking the IT outsourcing risks using fuzzy multicriteria decision-making" states: The Different Risks of Outsourcing Information Technology in Ghazvin Telecommunications Company, which in fact estimates these risks can help managers to make appropriate decisions to manage these risks. Shams and Sadeghi (2014) calculated the value-at-risk value of the Tehran Stock Exchange financial institutions. In this research, commonly used parametric and parametric methods for calculating value-at-risk values were introduced. Then, a very different parametric method called Cornish-Fisher was investigated from the normal distribution of the financial industry of the Tehran Stock Exchange including investment, insurance, leasing and banks in the years 20102012. Only 15 of the companies mentioned There was little difference with normal distribution. The dominant distribution in Iran's Bourt Company's financial institutions is not normal distribution. The findings of this study suggest that this turbidity works well for observations whose distribution is slightly different from normal distribution, and there is a significant difference between the calculation of risk value from both the normal and the Kornish-Fisher methods.

Foakeh (2013) explains in a paper entitled "The Effect of Risk Coverage Strategies on the Capital Market and its Impact on the Inclination to Invest (Case Study: Fars Exchange Market)": Investors can not logically Expect high returns without high risk. On the other hand, research has shown that individuals do not act reasonably and rationally in their decision-making under risk conditions. The results of the research showed that risk and its dimensions (initial risk, secondary risk, and non-financial risk) have a significant effect on the willingness to invest. 


\section{Methodology}

\subsection{Descriptive Statistics}

- Age range

The age range of respondents is shown in the table below:

Table 1. Distribution of respondents by age

\begin{tabular}{|c|c|c|c|}
\hline Age & Frequency & Percent & Cumulative Frequency \\
\hline$<30$ & 11 & 7.9 & 7.9 \\
\hline $31-40$ & 27 & 19.3 & 27.1 \\
\hline $41-50$ & 73 & 52.1 & 79.3 \\
\hline $50<$ & 29 & 20.7 & 100 \\
\hline Total & 140 & 100 & \\
\hline
\end{tabular}

As shown in Table 1, 7.9\% of respondents are less than 30 years old, $19.3 \%$ of respondents between 31 and 40 years old, $52.1 \%$ of respondents aged 41 to $50,20.7 \%$ more They are 50 years old.

\section{- Marital status}

The status quo of the respondents is shown in the table below:

Table 2. Distribution of respondents according to marital status

\begin{tabular}{|c|c|c|c|}
\hline Marital status & Frequency & Percent & Cumulative Frequency \\
\hline Married & 125 & 89.3 & 89.3 \\
\hline Single & 15 & 10.7 & 100 \\
\hline Total & 140 & 100 & \\
\hline
\end{tabular}

As shown in Table 2, 89.3\% of the respondents are married and $10.7 \%$ are single.

\section{- Academic status}

The academic status of respondents is shown in the table below:

Table 3. Distribution frequency of respondents according to academic status

\begin{tabular}{|c|c|c|c|}
\hline Academic status & Frequency & Percent & Cumulative Frequency \\
\hline Bachelor & 48 & 34.3 & 34.3 \\
\hline Master's degree & 78 & 55.7 & 90 \\
\hline P.H.D & 100 & 10 & 100 \\
\hline Total & 140 & 100 & \\
\hline
\end{tabular}

As shown in Table 3, 34.3\% had a bachelor's degree, 55.7\% had a master's degree, and $10 \%$ had a doctorate.

\subsection{Statistical analysis and hypothesis testing}

After describing the variables and the responses obtained from the statistical community in this section, research hypotheses are analyzed using regression coefficient.

\subsubsection{Descriptive Analysis}

In Table 4, the mean and standard deviation of all the variables of the research are stated. 
Table 4. Frequency of respondents based on work experience

\begin{tabular}{|c|c|c|c|c|c|}
\hline Variables & Number & Average & $\begin{array}{c}\text { Standard } \\
\text { deviation }\end{array}$ & Min & Max \\
\hline Early Risk & 98 & 3.71 & 0.512 & 2 & 5 \\
\hline Secondary Risk & 98 & 3.58 & 0.468 & 2 & 5 \\
\hline Non-Financial Risk & 98 & 3.75 & 0.479 & 2 & 5 \\
\hline Information Technology & 98 & 3.81 & .0410 & 2 & 5 \\
\hline Risk Management & 98 & 3.68 & 0.397 & 2 & 5 \\
\hline
\end{tabular}

\begin{tabular}{|c|c|c|c|c|c|}
\hline $\begin{array}{l}\text { Date: } 02 / 20 / 17 \\
\text { Time: } 01: 37\end{array}$ & & & & & \\
\hline \multicolumn{6}{|l|}{ Sample: 1140} \\
\hline & FANAVARI & $\begin{array}{c}\text { MODIRIYATE } \\
\text { RISK }\end{array}$ & $\underset{E}{\text { RISK_AVALIY }}$ & $\begin{array}{c}\text { RISK_SANAVI } \\
\text { YE }\end{array}$ & RISK_MALI \\
\hline Mean & 3.805458 & 3.678614 & 3.708929 & 3.579464 & 3.747449 \\
\hline Median & 3.875000 & 3.736607 & 3.750000 & 3.562500 & 3.785714 \\
\hline Maximum & 5.000000 & 4.732143 & 5.000000 & 4.875000 & 5.000000 \\
\hline Minimum & 2.350000 & 2.392857 & 2.125000 & 2.000000 & 2.357143 \\
\hline Std. Dev. & 0.409645 & 0.397366 & 0.512094 & 0.467638 & 0.479304 \\
\hline Skewness & -0.752813 & -0.592008 & -0.815020 & 0.129976 & -0.555789 \\
\hline Kurtosis & 1.152814 & 2.154324 & 3.267803 & 3.593215 & 3.125370 \\
\hline Jarque-Bera & 1.245884 & 1.935041 & 2.187539 & 2.446963 & 2.205283 \\
\hline Probability & 0.564324 & 0.432344 & 0.314544 & 0.294204 & 0.302240 \\
\hline Sum & 532.7642 & 515.0060 & 519.2500 & 501.1250 & 524.6429 \\
\hline Sum Sq. Dev. & 23.32542 & 21.94809 & 36.45134 & 30.39721 & 31.93276 \\
\hline Observations & 140 & 140 & 140 & 140 & 140 \\
\hline
\end{tabular}

Table 4 presents descriptive statistics for the research variables. The above table shows that the average of IT and risk management is above average (grade 3), which means that these two variables are in a good position. Meanwhile, IT has a higher average (3.81) of risk management (3.68).

\subsubsection{Inferential Analysis}

- Kolmogorov-Smirnov test to check the normal variables (k-s)

To use statistical techniques, it must first be determined that the collected data have normal distribution or abnormal. Because if the distribution of data is normal, the data collected for testing the hypotheses can be used as a parametric test, and in the case of non-normality, nonparametric tests. To this end, we examine the results of the KolmogorovSmirnov test on the variables studied and choose the appropriate tests based on the results. The results are presented in Table 5:

Table 5. The result of the test is the normality of the research variables

\begin{tabular}{|c|c|c|c|c|}
\hline Factor & Meaningful level & $\begin{array}{c}\text { Error } \\
\text { value }\end{array}$ & $\begin{array}{c}\text { Confirmation } \\
\text { of hypothesis }\end{array}$ & Conclusion \\
\hline Information Technology & 0.108 & 0.05 & $\mathrm{H}_{0}$ & Normal \\
\hline Risk management & 0.249 & 0.05 & $\mathrm{H}_{0}$ & Normal \\
\hline
\end{tabular}

According to the above table, since the level of significance for the two main components is larger than the error value of 0.05 , these variables have a normal distribution. 
- Stationary of research variables

In new econometric studies, it is necessary to examine the variables of the stationary before estimating the model. One variable when the mean of the variance and its correlation coefficients remain constant over time.

In general, if the time source of a stationary changes, and the mean and variance and covariance does not change, then the variable is unmatched and otherwise the variable will be invariant. Assumptions about the stationary of the variables are as follows:

$\left\{\mathrm{H}_{0}\right.$ : The variable is not stationary

$\left\{\mathrm{H}_{1}\right.$ :The variable is stationary

Stationary of variables can be investigated in three modes: "level", "first difference" and "second difference". Variables that have a probability of testing "at the level" of less than 5\%, the zero hypothesis is rejected, and that variable is at its stationary level; if it is more than $5 \%$, it is not stationary.

The results of the stationary test in the following tables are based on the output of the Eviews software for the variables. test in the following tables are based on the output of the Eviews software for the variables.

\begin{tabular}{|c|c|c|c|}
\hline \multicolumn{3}{|c|}{ Null Hypothesis: FANAVARI has a unit root } & \\
\hline \multicolumn{3}{|l|}{ Exogenous: Constant } & \\
\hline \multicolumn{4}{|c|}{ Lag Length: 1 (Automatic - based on SIC, maxlag=13) } \\
\hline & & t-Statistic & Prob.* \\
\hline \multicolumn{2}{|c|}{ Augmented Dickey-Fuller test statistic } & -6.288440 & 0.0000 \\
\hline \multirow[t]{3}{*}{ Test critical values: } & $1 \%$ level & -3.478189 & \\
\hline & $5 \%$ level & -2.882433 & \\
\hline & $10 \%$ level & -2.577990 & \\
\hline MacKinnon (199 & & & \\
\hline
\end{tabular}

Null Hypothesis: MODIRIYATE RISK has a unit root

Exogenous: Constant

Lag Length: 1 (Automatic - based on SIC, maxlag=13)

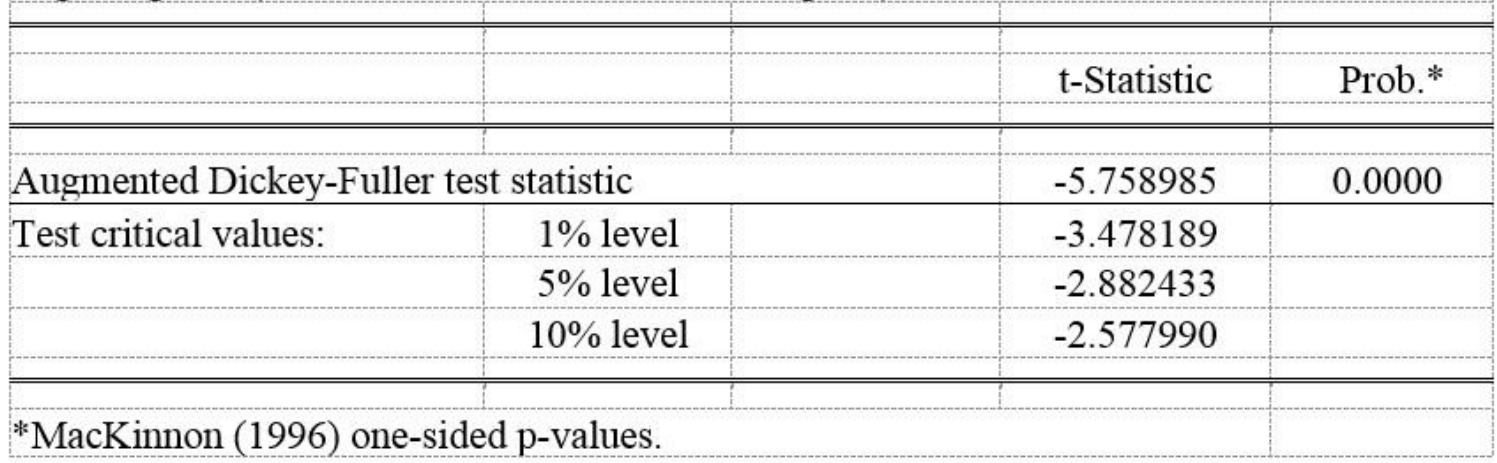


Null Hypothesis: RISK AVALIYE has a unit root

Exogenous: Constant

Lag Length: 1 (Automatic - based on SIC, maxlag=13)

\begin{tabular}{|c|c|c|c|}
\hline & & t-Statistic & Prob.* \\
\hline \multicolumn{2}{|c|}{ Augmented Dickey-Fuller test statistic } & -6.280430 & 0.0000 \\
\hline \multirow[t]{3}{*}{ Test critical values: } & $1 \%$ level & -3.478189 & \\
\hline & $5 \%$ level & -2.882433 & \\
\hline & $10 \%$ level & -2.577990 & \\
\hline Mac & & & \\
\hline
\end{tabular}

Null Hypothesis: RISK SANAVIYE has a unit root

Exogenous: Constant

Lag Length: 1 (Automatic - based on SIC, maxlag=13)

\begin{tabular}{|c|c|c|c|}
\hline & & t-Statistic & Prob.* \\
\hline \multicolumn{2}{|c|}{ Augmented Dickey-Fuller test statistic } & -5.498662 & 0.0000 \\
\hline \multirow[t]{3}{*}{ Test critical values: } & $1 \%$ level & -3.478189 & \\
\hline & $5 \%$ level & -2.882433 & \\
\hline & $10 \%$ level & -2.577990 & \\
\hline
\end{tabular}

Null Hypothesis: RISK MALI has a unit root

Exogenous: Constant

Lag Length: 1 (Automatic - based on SIC, maxlag=13)

\begin{tabular}{|c|c|c|c|}
\hline & & t-Statistic & Prob.* \\
\hline \multicolumn{2}{|c|}{ Augmented Dickey-Fuller test statistic } & -6.548889 & 0.0000 \\
\hline \multirow[t]{3}{*}{ Test critical values: } & $1 \%$ level & -3.478189 & \\
\hline & $5 \%$ level & -2.882433 & \\
\hline & $10 \%$ level & -2.577990 & \\
\hline
\end{tabular}

The result of the stationary test shows that all variables are static (stationary) at the stable level. 
- Root test (static) of the variables group

Group unit root test: Summary

Series: FANAVARI, MODIRIYATE_RISK, RISK_AVALIYE, RISK_SANAVIYE, RISK MALI

Date: 02/20/17 Time: 01:40

Sample: 1140

Exogenous variables: Individual effects

Automatic selection of maximum lags

Automatic lag length selection based on SIC: 1

Newey-West automatic bandwidth selection and Bartlett kernel

Balanced observations for each test

\begin{tabular}{|l|c|c|c|c|}
\hline \hline & & & & \\
& & & Cross- & \\
\hline Method & Statistic & Prob.** & sections & Obs \\
\hline
\end{tabular}

Null: Unit root (assumes common unit root process)

Levin, Lin \& Chu t*

$-12.6466$

0.0000

5

690

Null: Unit root (assumes individual unit root process)

Im, Pesaran and Shin W-stat

$-11.7747$

$\mathrm{ADF}$ - Fisher Chi-square

146.807

370.464

0.0000
0.0000
0.0000

690

PP - Fisher Chi-square

690

695

\section{** Probabilities for Fisher tests are computed using an asymptotic Chi}

-square distribution. All other tests assume asymptotic normality.

The result of the stationary test shows that all variables are static (stationary) at the stable level.

- Survey correlation coefficients of research variables

The severity of the dependence of the two variables defines one another as a correlation. Generally, the correlation coefficients vary between 1 and 1, and the relationship between the two variables can be positive or negative. The correlation coefficient is a symmetric relationship, whatever the closer the correlation coefficient is to one, the greater the dependence of the two variables. This dependence does not mean the cause and effect relationship, and the correlation coefficient does not reveal which cause and cause is affected. The correlation test examines the relationship between variables and according to the results, it can be said that there is a relationship between the variables and a more precise examination of these relationships can be made. For example, the results obtained from the correlation coefficient table show that there is a direct relation between (Fanavari) and (modiriyate-risk) $87 \%$, and there is significant statistical significance. Also, there is a positive correlation between (Fanavari) and (risk-mali) $84 \%$ and statistically significant. 


\begin{tabular}{|c|c|c|c|c|c|}
\hline \multicolumn{6}{|c|}{ Covariance Analysis: Ordinary } \\
\hline \multicolumn{6}{|c|}{ Date: $02 / 20 / 17$ Time: $01: 38$} \\
\hline \multicolumn{6}{|c|}{ Sample: 1140} \\
\hline \multicolumn{6}{|c|}{ Included observations: 140} \\
\hline \multicolumn{6}{|c|}{ Covariance } \\
\hline \multicolumn{6}{|c|}{ Correlation } \\
\hline \multicolumn{6}{|c|}{ t-Statistic } \\
\hline Probability & FANAVARI & $\begin{array}{c}\text { MODIRIYATE } \\
\text { RISK }\end{array}$ & RISK_AVALIYE & $\underset{\text { YE }}{\text { RISK_SANAVI }}$ & RISK_MAII \\
\hline \multirow[t]{4}{*}{ FANAVARI } & 0.166610 & & & & \\
\hline & 1.000000 & & & & \\
\hline & $\ldots$ & & & & \\
\hline & $\cdots$ & & & & \\
\hline & & & & & \\
\hline \multirow[t]{4}{*}{ MODIRIYATE_RISK } & 0.140693 & 0.156772 & & & \\
\hline & 0.870539 & 1.000000 & & & \\
\hline & 20.78140 & $\cdots$ & & & \\
\hline & 0.0000 & $\cdots$ & & & \\
\hline & & & & & \\
\hline \multirow[t]{4}{*}{ RISK AVALIYE } & 0.167051 & 0.177625 & 0.260367 & & \\
\hline & 0.802057 & 0.879176 & 1.000000 & & \\
\hline & 15.77578 & 21.67479 & $\cdots$ & & \\
\hline & 0.0000 & 0.0000 & $\cdots$ & & \\
\hline \multirow[t]{4}{*}{ RISK_SANAVIYE } & 0.091393 & 0.132870 & 0.101311 & 0.217123 & \\
\hline & 0.480516 & 0.720179 & 0.426098 & 1.000000 & \\
\hline & 6.436574 & 12.19419 & 5.532930 & $\cdots$ & \\
\hline & 0.0000 & 0.0000 & 0.0000 & $\cdots$ & \\
\hline \multirow[t]{4}{*}{ RISK_MALI } & 0.163636 & 0.159822 & 0.171196 & 0.080177 & 0.228091 \\
\hline & 0.839411 & 0.845175 & 0.702502 & 0.360283 & 1.000000 \\
\hline & 18.14329 & 18.57578 & 11.59580 & 4.537063 & $\cdots$ \\
\hline & 0.0000 & 0.0000 & 0.0000 & 0.0000 & 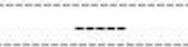 \\
\hline
\end{tabular}

\subsection{Test of research hypotheses}

3.3.1 Test of first hypothesis:

After verifying the structure of the research structures, structural equation modeling has been used to study the relationships between the variables.

Regression test was used to investigate the effect of information technology on risk management in capital markets. The hypothesis is as follows:

Information technology affects risk management in the capital market of companies accepted in Tehran Stock Exchange.

$\bmod$ iriyat - risk $k_{t}=\beta_{0}+\beta_{1}$ fana $\operatorname{var} i_{t}+\varepsilon_{t}$ 
The results of regression are summarized in Table 6:

\begin{tabular}{|c|c|c|c|c|}
\hline \multicolumn{4}{|c|}{ Dependent Variable: MODIRIYATE RISK } & \\
\hline \multicolumn{5}{|c|}{ Method: Least Squares } \\
\hline \multicolumn{5}{|c|}{ Date: $02 / 20 / 17$ Time: $01: 47$} \\
\hline \multicolumn{5}{|l|}{ Sample: 1140} \\
\hline \multicolumn{5}{|c|}{ Included observations: 140} \\
\hline Variable & Coefficient & Std. Error & t-Statistic & Prob. \\
\hline FANAVARI & 0.844446 & 0.040635 & 20.78140 & 0.0000 \\
\hline $\mathrm{C}$ & 0.465110 & 0.155521 & 2.990664 & 0.0033 \\
\hline R-squared & 0.757838 & \multicolumn{2}{|c|}{ Mean dependent var } & 3.678614 \\
\hline Adjusted R-squared & 0.756083 & \multicolumn{2}{|c|}{ S.D. dependent var } & 0.397366 \\
\hline S.E. of regression & 0.196251 & \multicolumn{2}{|c|}{ Akaike info criterion } & -0.404662 \\
\hline Sum squared resid & 5.314993 & \multicolumn{2}{|c|}{ Schwarz criterion } & -0.362639 \\
\hline Log likelihood & 30.32635 & \multicolumn{2}{|c|}{ Hannan-Quinn criter. } & -0.387585 \\
\hline F-statistic & 431.8666 & \multicolumn{2}{|c|}{ Durbin-Watson stat } & 1.231963 \\
\hline Prob(F-statistic) & 0.000000 & & & \\
\hline
\end{tabular}

\begin{tabular}{|l|r|r|r|}
\hline Heteroskedasticity Test: ARCH & & \\
\hline \hline F-statistic & 0.452364 & Prob. F(1,137) & \\
\hline Obs*R-squared & 0.457458 & Prob. Chi-Square(1) & 0.5023 \\
\hline \hline
\end{tabular}

Table 6. Results of Information Technology Regression Analysis in Risk Management in the Capital Market

\begin{tabular}{|c|c|c|c|c|c|}
\hline $\begin{array}{l}\text { Criterion } \\
\text { variable }\end{array}$ & $\begin{array}{l}\text { Predictive } \\
\text { variable }\end{array}$ & $\begin{array}{c}\text { Correlation } \\
\text { MR }\end{array}$ & $\begin{array}{l}\text { The coefficient of } \\
\text { determination } \\
\text { RS }\end{array}$ & $\begin{array}{c}\text { Ratio F } \\
\text { Possibility P }\end{array}$ & $\begin{array}{c}\text { The regression } \\
\text { coefficient }\end{array}$ \\
\hline $\begin{array}{c}\text { Information } \\
\text { Technology }\end{array}$ & $\begin{array}{c}\text { Risk } \\
\text { Management }\end{array}$ & 0.844 & 0.758 & $\begin{array}{c}F=431.867 \\
P=0.00\end{array}$ & $\begin{array}{c}\beta=0.844 \\
t=20.781 \\
p=0.00\end{array}$ \\
\hline
\end{tabular}

The results of the regression model analysis of the relationship between the two variables are presented in Table 6 . The standard beta coefficient between the two variables of information technology and risk management is 0.844 . The value of $\mathrm{t}$ statistic is also 20.781, which indicates that the observed correlation is significant; therefore, with 95\% confidence, IT management has a direct impact on risk management. On the other hand, the beta coefficient of the standard between the two variables is total quality management and financial performance of $30 \%$; therefore, with $95 \%$ confidence, comprehensive quality management has a direct effect on financial performance.

\subsubsection{Test of second hypothesis:}

Regression test was used to investigate the impact of information technology on the market primitive risk. The hypothesis is as follows: 
Information technology affects the primary market risk of the listed companies in the Tehran Stock Exchange.

risk - avaliye ${ }_{t}=\beta_{0}+\beta_{1}$ fana var $i_{t}+\varepsilon_{t}$

Test results The hypothesis of the study is described in Table 7.

Dependent Variable: RISK AVALIYE

Method: Least Squares

Date: 02/20/17 Time: 01:56

Sample: 1140

Included observations: 140

\begin{tabular}{|c|c|c|c|c|}
\hline Variable & Coefficient & Std. Error & t-Statistic & Prob. \\
\hline FANAVARI & 1.002646 & 0.063556 & 15.77578 & 0.0000 \\
\hline $\mathrm{C}$ & -0.106597 & 0.243247 & -0.438227 & 0.6619 \\
\hline R-squared & 0.643296 & \multicolumn{2}{|c|}{ Mean dependent var } & 3.708929 \\
\hline Adjusted R-squared & 0.640711 & \multicolumn{2}{|c|}{ S.D. dependent var } & 0.512094 \\
\hline S.E. of regression & 0.306953 & \multicolumn{2}{|c|}{ Akaike info criterion } & 0.48993 \\
\hline Sum squared resid & 13.00234 & \multicolumn{2}{|c|}{ Schwarz criterion } & 0.531959 \\
\hline Log likelihood & -32.29547 & \multicolumn{2}{|c|}{ Hannan-Quinn criter. } & 0.507012 \\
\hline F-statistic & 248.8754 & \multicolumn{2}{|c|}{ Durbin-Watson stat } & 1.855177 \\
\hline Prob(F-statistic) & 0.000000 & & & \\
\hline
\end{tabular}

\begin{tabular}{|l|r|r|r|}
\hline Heteroskedasticity Test: ARCH & & \\
\hline \hline F-statistic & 0.315292 & Prob. F(1,137) & \\
\hline Obs*R-squared & 0.319160 & Prob. Chi-Square(1) & 0.5754 \\
\hline \hline
\end{tabular}

Table 7. Results of Information Technology Regression Analysis on Primary Market Risk

\begin{tabular}{|c|c|c|c|c|c|}
\hline $\begin{array}{c}\text { Criterion } \\
\text { variable }\end{array}$ & $\begin{array}{c}\text { Predictive } \\
\text { variable }\end{array}$ & Correlation MR & $\begin{array}{c}\text { The coefficient of } \\
\text { determination } \\
\mathrm{RS}\end{array}$ & $\begin{array}{c}\text { Ratio F } \\
\text { Possibility P }\end{array}$ & $\begin{array}{c}\text { The regression } \\
\text { coefficient }\end{array}$ \\
\hline $\begin{array}{c}\text { Information } \\
\text { Technology }\end{array}$ & $\begin{array}{c}\text { Primary } \\
\text { market risk }\end{array}$ & 1.002 & 0.643 & $\begin{array}{c}\mathrm{F}=248.875 \\
\mathrm{P}=0.00\end{array}$ & $\begin{array}{c}\beta=1.002 \\
\mathrm{t}=15.776 \\
\mathrm{p}=0.00\end{array}$ \\
\hline
\end{tabular}

The results show that the standard beta coefficient between the two IT variables was obtained on the initial market risk of 1.002. The value of $\mathrm{t}$ statistic was also 15.776, which indicates that the correlation observed is significant; therefore, with 95\% confidence, information technology has a direct impact on the initial market risk. 
3.3.3 Test of third hypothesis:

Regression test was used to investigate the impact of information technology on the market risk. The hypothesis is as follows:

Information technology affects the risk of the secondary market of listed companies in Tehran Stock Exchange.

risk - savaviye $_{t}=\beta_{0}+\beta_{1}$ fana var $i_{t}+\varepsilon_{t}$

Test results The hypothesis of the survey is described in Table 8 .

\begin{tabular}{|c|c|c|c|c|}
\hline \multicolumn{4}{|c|}{ Dependent Variable: RISK SANAVIYE } & \\
\hline \multicolumn{5}{|c|}{ Method: Least Squares } \\
\hline \multicolumn{5}{|c|}{ Date: $02 / 20 / 17$ Time: $02: 00$} \\
\hline \multicolumn{5}{|l|}{ Sample: 1140} \\
\hline \multicolumn{5}{|c|}{ Included observations: 140} \\
\hline Variable & Coefficient & Std. Error & t-Statistic & Prob. \\
\hline FANAVARI & 0.548542 & 0.085223 & 6.436574 & 0.0000 \\
\hline $\mathrm{C}$ & 1.492010 & 0.326172 & 4.574310 & 0.0000 \\
\hline R-squared & 0.230896 & \multicolumn{2}{|c|}{ Mean dependent var } & 3.579464 \\
\hline Adjusted R-squared & 0.225322 & \multicolumn{2}{|c|}{ S.D. dependent var } & 0.467638 \\
\hline S.E. of regression & 0.411595 & \multicolumn{2}{|c|}{ Akaike info criterion } & 1.076628 \\
\hline Sum squared resid & 23.37863 & \multicolumn{2}{|c|}{ Schwarz criterion } & 1.118652 \\
\hline Log likelihood & -73.36398 & \multicolumn{2}{|c|}{ Hannan-Quinn criter. } & 1.093705 \\
\hline F-statistic & 41.42948 & \multicolumn{2}{|c|}{ Durbin-Watson stat } & 1.314111 \\
\hline Prob(F-statistic) & 0.000000 & & & \\
\hline
\end{tabular}

\begin{tabular}{|l|l|r|r|}
\hline Heteroskedasticity Test: ARCH & & \\
\hline \hline F-statistic & 0.122636 & Prob. F(1,137) & \\
\hline Obs*R-squared & 0.124315 & Prob. Chi-Square(1) & 0.7267 \\
\hline \hline
\end{tabular}

Table 8. Results of Information Technology Regression Analysis on Primary Market Risk

\begin{tabular}{|c|c|c|c|c|c|}
\hline $\begin{array}{c}\text { Criterion } \\
\text { variable }\end{array}$ & $\begin{array}{c}\text { Predictive } \\
\text { variable }\end{array}$ & Correlation MR & $\begin{array}{c}\text { The coefficient of } \\
\text { determination } \\
\text { RS }\end{array}$ & $\begin{array}{c}\text { Ratio F } \\
\text { Possibility P }\end{array}$ & $\begin{array}{c}\text { The regression } \\
\text { coefficient }\end{array}$ \\
\hline $\begin{array}{c}\text { Information } \\
\text { Technology }\end{array}$ & $\begin{array}{c}\text { Secondary } \\
\text { Market Risk }\end{array}$ & 0.548 & 0.231 & $\begin{array}{c}\mathrm{F}=41.429 \\
\mathrm{P}=0.00\end{array}$ & $\begin{array}{c}\beta=0.548 \\
\mathrm{t}=6.437 \\
\mathrm{p}=0.00\end{array}$ \\
\hline
\end{tabular}

The regression equation with $\mathrm{F}=41.429$ and the significance level of 0.00 , which is smaller than 0.05 , is significant; therefore, it is assumed that there is a linear relationship between the variables of the research.

The results of regression analysis using step-by-step method show that the regression coefficient for secondary market risk is $\beta=0.548$ and the significance test statistic of the regression coefficient was $t=6.4377$, and its 
significance level is $0 / 00$ which is less than and 0.05 . Therefore, with $95 \%$ accuracy, information technology has a direct impact on the secondary market risk.

3.3.4 Test of fourth hypothesis:

Regression test was used to investigate the effect of information technology on non-financial risk. The hypothesis is as follows:

Information technology affects the non-financial risk of accepted companies in Tehran Stock Exchange.

risk - mali ${ }_{t}=\beta_{0}+\beta_{1}$ fana var $i_{t}+\varepsilon_{t}$

The test results of the test hypothesis are described in Table 9.

\begin{tabular}{|c|c|c|c|c|}
\hline \multicolumn{5}{|c|}{ Dependent Variable: RISK_MALI } \\
\hline \multicolumn{5}{|c|}{ Method: Least Squares } \\
\hline \multicolumn{5}{|c|}{ Date: $02 / 20 / 17$ Time: $02: 03$} \\
\hline \multicolumn{5}{|c|}{ Sample: 1140} \\
\hline \multicolumn{5}{|c|}{ Included observations: 140} \\
\hline Variable & Coefficient & Std. Error & t-Statistic & Prob. \\
\hline FANAVARI & 0.982150 & 0.054133 & 18.14329 & 0.0000 \\
\hline $\mathrm{C}$ & 0.009917 & 0.207182 & 0.047866 & 0.9619 \\
\hline R-squared & 0.704610 & \multicolumn{2}{|c|}{ Mean dependent var } & 3.747449 \\
\hline Adjusted R-squared & 0.702470 & \multicolumn{2}{|c|}{ S.D. dependent var } & 0.479304 \\
\hline S.E. of regression & 0.261443 & \multicolumn{2}{|c|}{ Akaike info criterion } & 0.168980 \\
\hline Sum squared resid & 9.432616 & \multicolumn{2}{|c|}{ Schwarz criterion } & 0.211003 \\
\hline Log likelihood & -9.828569 & \multicolumn{2}{|c|}{ Hannan-Quinn criter. } & 0.186057 \\
\hline F-statistic & 329.1791 & \multicolumn{2}{|c|}{ Durbin-Watson stat } & 2.140403 \\
\hline Prob(F-statistic) & 0.000000 & & & \\
\hline
\end{tabular}

\begin{tabular}{|c|c|c|c|}
\hline \multicolumn{3}{|c|}{ Breusch-Godfrey Serial Correlation LM Test: } & \\
\hline F-statistic & 1.723673 & Prob. $F(2,136)$ & 0.1823 \\
\hline Obs*R-squared & 3.461008 & Prob. Chi-Square(2) & 0.1772 \\
\hline
\end{tabular}

\begin{tabular}{|c|c|c|c|}
\hline \multicolumn{3}{|c|}{ Heteroskedasticity Test: White } & \\
\hline \hline F-statistic & 1.967316 & Prob. F(2,137) & 0.1438 \\
\hline Obs*R-squared & 3.908538 & Prob. Chi-Square(2) & 0.1417 \\
\hline Scaled explained SS & 5.753862 & Prob. Chi-Square(2) & 0.0563 \\
\hline \hline
\end{tabular}


Table 9. Results of Information Technology Regression Analysis on Non-financial Risk

\begin{tabular}{|c|c|c|c|c|c|}
\hline $\begin{array}{c}\text { Criterion } \\
\text { Variable }\end{array}$ & Predictive Variable & Correlation MR & $\begin{array}{c}\text { Coefficient of } \\
\text { Determination } \\
\text { RS }\end{array}$ & $\begin{array}{c}\text { Ratio F } \\
\text { Possibility P }\end{array}$ & $\begin{array}{c}\text { Regression } \\
\text { Coefficient }\end{array}$ \\
\hline $\begin{array}{c}\text { Information } \\
\text { Technology }\end{array}$ & Non-financial risk & 0.982 & 0.705 & $\begin{array}{c}\mathrm{F}=329.179 \\
\mathrm{P}=0.00\end{array}$ & $\begin{array}{c}\beta=0.982 \\
\mathrm{t}=18.143 \\
\mathrm{p}=0.00\end{array}$ \\
\hline
\end{tabular}

The regression equation is significant with $\mathrm{F}=31.48$ and the significance level of 0.03 , which is smaller than 0.05 , so it is assumed that there is a linear relationship between the research variables.

The results of regression analysis using step-by-step method show that the regression coefficient for non-financial risk is $\beta=0.982$ and the significance test statistic of t-test $=18.143$ for the regression coefficient and its significance level is 0.00 , which is less than and 0.05 ; Therefore, with $95 \%$ confidence, information technology has a direct impact on non-financial risk.

\subsection{The effect of demographic characteristics on research variables}

In the following, we examine each of the demographic variables on the research variables:

\section{- Marital Status}

To evaluate the impact of information technology on risk management with their marital status, independent $t$ test is used, the results are presented in Table 10.

Table 10. Independent t-test results in terms of marital status

\begin{tabular}{|c|c|c|c|c|c|}
\hline Variable & Marital status & Average & $\begin{array}{c}\text { Standard } \\
\text { Deviation }\end{array}$ & $\mathbf{T}$ & Sig \\
\hline \multirow{2}{*}{$\begin{array}{l}\text { Information } \\
\text { Technology }\end{array}$} & Single & 111.3 & 16.652 & \multirow{2}{*}{2.33} & \multirow{2}{*}{0.06} \\
\hline & Married & 194.7 & 14.781 & & \\
\hline \multirow{2}{*}{ Risk Management } & Single & 185.2 & 14.391 & \multirow{2}{*}{2.91} & \multirow{2}{*}{0.08} \\
\hline & Married & 123.7 & 13.207 & & \\
\hline
\end{tabular}

In the table above, the results of independent t-test show that there is no significant difference between the information technology and risk management (95\% confidence level) ( $\mathrm{p}<0.05)$; in other words, the impact of information technology and risk management among the single and married respondents is the same.

\section{- Education}

To evaluate the impact of information technology on risk management with their education, independent $t$ test is used, the results are presented in Table 11.

Table 11. Independent t-test results in terms of educational qualification

\begin{tabular}{|c|c|c|c|c|c|}
\hline Variable & Education & Sum of squares & Average squares & $\mathbf{F}$ & Sig \\
\hline \multirow{2}{*}{$\begin{array}{l}\text { Information } \\
\text { Technology }\end{array}$} & In group & 74.562 & 34.378 & \multirow{2}{*}{0.380} & \multirow{2}{*}{0.66} \\
\hline & Inter group & 502.922 & 625.364 & & \\
\hline \multirow{2}{*}{ Risk Management } & In group & 364.631 & 67.456 & \multirow{2}{*}{0.341} & \multirow{2}{*}{0.40} \\
\hline & Inter group & 527.128 & 710.940 & & \\
\hline
\end{tabular}

The results of the above table indicate that the impact of information technology on risk management based on education level with $\mathrm{F}=0.380$ and $\mathrm{F}=0.341$ does not show significant difference at $95 \%$ confidence level; therefore, between the impact of information technology There is no significant difference in risk management according to their degree. 
- Age

To evaluate the impact of information technology on risk management with their education, independent $t$ test is used, the results are presented in Table 12.

Table 12. Independent t-test results in terms of age

\begin{tabular}{|c|c|c|c|c|c|}
\hline Variable & Age & Sum of squares & Average squares & $\mathbf{F}$ & Sig \\
\hline \multirow{2}{*}{$\begin{array}{l}\text { Information } \\
\text { Technology }\end{array}$} & In group & 60.520 & 37.378 & \multirow{2}{*}{0.412} & \multirow{2}{*}{0.33} \\
\hline & Inter group & 570.243 & 325.364 & & \\
\hline \multirow{2}{*}{ Risk Management } & In group & 63.380 & 44.396 & \multirow{2}{*}{0.252} & \multirow{2}{*}{0.30} \\
\hline & Inter group & 507.637 & 258.331 & & \\
\hline
\end{tabular}

The results presented in the table above indicate that the impact of information technology on risk management based on age $(\mathrm{F}=0.412$ and $\mathrm{F}=0.252)$ does not show significant difference at $95 \%$ confidence level; therefore, the impact of information technology on Risk management is not significantly different from their age.

\section{Conclusion}

According to the first hypothesis, it can be concluded that information technology affects risk management in the capital market of companies accepted in Tehran Stock Exchange. Information technology has a role to play in the realization of the goals of every business. And, of course, the issue of risk management requires internal control by information technology. The focus on information technology and risk management in the Stock Exchange is because it is safe to say that the role of risk management empowerment in this area has become very important in recent years. Today, risk management is vital for the continued operation of financial institutions in the capital market. Risk management is very important and highly recommended in Islam. The result of this study is consistent with researchers such as Hobijn and Jovanovic (2011).

According to the second hypothesis, it can be concluded that information technology affects the market risk of the companies accepted in Tehran Stock Exchange. The result of this study is consistent with researchers such as Ahmadpour Kasegari (2014). Because most investments in the stock market occur in the secondary market, and only stock exchanges are traded on this market, ie the ownership of shares is transferred from one person to another, and equity holders are also due to an increase in the stock price or the profit of that unit The annual production is benefited, so this does not necessarily reduce the people's referrals to the banks for investment; therefore, this money will not necessarily come to the hands of the investor unless it comes into the initial market, in which case Can be a good solution It is a strengthening of the capital market, and our values are consistent, but must be limited to the primary market, and in this market either the production unit must increase its capital and expand its activities, or there should be a new unit that will set up the stock in accordance with the provisions in there is a capital market to sell.

According to the third hypothesis, it can be concluded that information technology affects the risk of the secondary market of companies accepted in Tehran Stock Exchange. The result of this study is consistent with (2013). As the primary market should be active in order to be able to play a role in long-term financing of stock markets, the secondary market should also flourish, as the government program, the liberalization of equity shares, and the ability to trade shares in the stock exchange, and the success of this program, Capital market prosperity, especially the secondary market, is why the prosperity of both primary and secondary markets is considered by the government as complementary markets for each other.

According to the fourth hypothesis, it can be concluded that information technology affects the non-financial risk of accepted companies in Tehran Stock Exchange, which is consistent with the results of Mirzaee et al. (2011) and Van Horne (2008). In turbulent environments where organizations face threats to survival, risk-based approaches can be very effective in many cases. Therefore, to provide a comprehensive strategy for managing large organizations, we need to develop frameworks and models for non-financial risk indicators at macro and strategic levels, and with an integrated, cross-sectoral approach.

\section{Reference}

Bhattacherjee, A. Premkumar, G. (2011). Explaining Information Technology Usage:A test of Competing Models. Omega(36). 
Farajollahi, Masoomeh. (2015). Risk Management, Second Management Conference and Applied Economics with National Approaches.

Favakeh, Farshad (2013) Investigating the Effect of Risk Coverage Strategies on the Capital Market and Its Impact on the Inclination to Invest (Case Study: Fars Magazine), Master's thesis of Kerman Islamic Azad University.

Fathi, Hossein., Nazariye Pardazan, Rafigh., \& Bagheri, Rana. (2011). "Investigating the Factors Affecting Credit Risk of Legal Persons of Banks (A Case Study of National Bank of Iran Branches, Tehran City)", Quarterly Journal of Economic Research, Vol. 19, No. 58.

Group of Advisers of Exchange, (2013), vacancy of risk control tool in financial markets of the country, economy of the world, No. 2963.

Gholizadeh, Hasan., Kazemian, Shohreh. (2012). Analysis of various risk coverage methods in the capital market of the country and providing appropriate methods within the framework of the Islamic economic system, National Conference on Accounting, Financial Management and Investment, Golestan University of Applied Sciences.

Kang, Y., Hong, S., \& Lee, H. (2012). Exploring Continued Online Service Usage Behavior: The Roles of SelfImage Congruity and Regret. Computers in Human Behavior(25).

Kouroubali, A. Tisknakis, M., (2012). Organizational Factors Affecting Successful Adoption of Innovative EHealth Services: A Case Study Employing the FITT Framework. Int. J. Medical Informatics(78).

Manzor, Davood,. niyakan, Leyli,. Mohammadi, Arash. (2013), Risk Management in the Electricity Industry of Iran: Essentials and Tools, Iranian Energy Journal, No. 4.

Rood Pashti, Fereydoun., Rezaei, Ahmad., \& Moghaddami, Afshin. (2011). Strategic financial management (valueadded), Foundation for Industry and Development.

Soroush, Abuzar and Sadeghi, Mohsen. (2013). Risk Management for Rental Securities, Journal of Islamic Economics, Tehran, Islamic Culture and Thought Research Center, 27.

Sahebnam, Hadi., Kharqani, Mehdi., Goli, Samira., \& Abbasi Zomehri, Mehdi. (2014), Investigating the Integrated Engineering Model of Labor Study and Successful Settlement in the Capital Market (Tehran Stock Exchange). International Conference on Accounting, Economics and Financial Management, Tehran, Knowledge-Driven Firm, http://www.civilica.com/Paper-AEFMC01-AEFMC01_030.html.

Samadi, Mansour. (2012), Consumer Behavior, Aijj Publishing, Tehran, Second Edition.

Shiva, Reza., Micaelpour, Hussein. (2012). Risk Management in the Banking Sector, Lecture Series and Articles of the Fourth Islamic Banking Conference, Tehran, Iran's High School of Banking, First Edition.

Tam, K. Thong, J., Hong, S. (2010). The Effects of Post Adoption Beliefs on the Expectation-Confirmation Model for Information Technology Continuance. Int. J. Human-Computer.

Tahani, N. Li. X, (2011), Pricing interest are derivatives under stochastic Volatility Managerial Finance,Vol. 37.

Sundarraj, R. P., and Wu, J., (2010), Using Information-Systems Constructs to Study Online- and TelephoneBanking Technologies, Electronic Commerce Research and Applications, 4. 